\title{
PENGARUH KUALITAS PERAIRAN TERHADAP DISTRIBUSI VERTIKAL PLANKTON DI SAMUDERA HINDIA BAGIAN SELATAN INDONESIA
}

\section{THE INFL UENCE OF WATER QUALITYONTHE PLANKTONVERTICALDISTRIBUTION IN THE SOUTHERN PART OF INDIAN OCEAN, INDONESIA}

\author{
Mega Oceanna ${ }^{1}$, Agustin Rustam², Eva Mustikasari $^{2}$, \& Aida Heriati ${ }^{2}$ \\ ${ }^{1}$ Universitas Gadjah Mada \\ Jl. Flora 1 Bulaksumur Yogyakarta, +6281290037815 \\ ${ }^{2}$ Pusat Riset Kelautan, Badan Riset dan Sumber Daya Manusia Kelautan dan Perikanan, Kementerian Kelautan dan Perikanan \\ Jl. Pasir Putih I, Ancol Timur, Jakarta Utara \\ e-mail : megaoceanna6@gmail.com
}

Diterima tanggal: 14 Juni 2017 ; diterima setelah perbaikan: 30 Agustus 2021 ; Disetujui tanggal: 05 September 2021

\begin{abstract}
ABSTRAK
Perairan selatan Indonesia memiliki kondisi batimetri yang unik, begitu pula dengan kondisi kualitas perairan di dalamnya yang selanjutnya akan mempengaruhi biota perairan. Penelitian dilakukan pada April 2008 dengan menempatkan 4 titik stasiun, dari mulai Selat Sunda hingga menuju ke Pameungpeuk Garut yang merupakan daerah Samudera Hindia. Pengamatan terhadap kualitas air dilakukan dengan menggunakan Conductivity Temperature Depth (CTD), sedangkan pengamatan plankton dilakukan dengan sampling plankton menggunakan Rosette Sampler. Profil suhu dan salinitas menunjukkan adanya perubahan nilai pada kedalaman sekitar $75 \mathrm{~m}$. Plankton yang paling banyak ditemukan adalah genus Chaetoceros. Kelimpahan fitoplankton tertinggi adalah $6.825 \mathrm{ind} / \mathrm{L}$ yang terjadi pada kedalaman $50 \mathrm{~m}$ di stasiun 5 dan kelimpahan zooplankton tertinggi adalah 1.708 ind/L yang terjadi pada kedalaman $50 \mathrm{~m}$ di stasiun 3. Sebaran horizontal menunjukkan semakin dekat daratan, suhu bernilai tinggi dan salinitas bernilai rendah.
\end{abstract}

Kata kunci: Plankton, kualitas air, samudera hindia, kedalaman, suhu, salinitas.

\begin{abstract}
Southern part of Indonesia waters has a unique bathymetric conditions as well as water quality condition that affect aquatic biota in the region. The research was conducted on April 2008 within 4 stations in Indian Ocean, starting from Sunda Strait to Pameungpeuk Garut. Observations on water quality was conducted using Conductivity Temperature Depth (CTD), whereas sampling plankton observations were carried out using a Rosette Sampler. The temperature and salinity profiles started to change at $75 \mathrm{~m}$ depth. The dominant plankton found is the genus Chaetoceros. The highest concentration of phytoplankton was $6,825 \mathrm{ind} / \mathrm{L}$ at a depth of $50 \mathrm{~m}$ in station 5, on the other hand, highest concentration of zooplankton was 1,708 ind/L $50 \mathrm{~m}$ depth in station 3. Horizontal distribution shows that the condition of temperature (high) and salinity (lower) near coastal area.
\end{abstract}

Keywords: plankton, water quality, indian ocean, depth, temperature, salinityKeywords: depth, plankton, station. 


\section{PENDAHULUAN}

Selat Sunda merupakan selat yang memiliki pengaruh dari Laut Jawa di bagian utara dan Samudera Hindia di bagian selatan. Pencampuran air tersebut didorong oleh perbedaan arus sehingga menimbulkan karakteristik massa air yang unik untuk setiap daerah. Parameter yang sangat dipengaruhi adalah suhu dan salinitas. Suhu akan berubah drastis pada lapisan termoklin yang akan memicu terjadinya kenaikan massa air laut dari dasar laut ke permukaan upwelling yang dimulai dengan menurunnya kestabilan kolom air yang menunjukkan pelemahan stratifikasi massa air, kemudian diikuti dengan naiknya massa air dari lapisan dalam ke permukaan dengan suhu yang rendah (Novia et al., 2016). Peristiwa upwelling dapat memberikan keuntungan karena dianggap sebagai waktu yang tepat untuk melakukan penangkapan ikan. Namun, peristiwa ini dapat menjadi buruk apabila terlalu banyak nutrien yang teraduk ke permukaan sehingga menyebabkan terjadinya meningkatnya konsentrasi alga yang berbahaya Harmful Algal Blooms (HABs).

Selat Sunda hingga Pameungpeuk Garut merupakan perairan yang masih memiliki pengaruh dari daratan dan juga terpengaruh oleh lautan lepas. Aktivitas yang dilakukan manusia, seperti penggunaan deterjen dan pestisida di daratan akan memberikan dampak terhadap perairan melalui aliran sungai yang membawa polutan tadi dari hulu hingga ke hilir, proses ini biasa disebut runoff. Proses runoff membawa nutrien dan unsur hara yang selanjutnya mengendap di bawah laut yang berperan dalam proses dan perkembangan organisme hidup, seperti fitoplankton (Wang et al., 2015) yang apabila terjadi upwelling maka akan naik ke permukaan laut dan menjadi makanan bagi fitoplankton.

Perairan Pameungpeuk Garut merupakan perairan yang merupakan muara dari beberapa sungai, yaitu Sungai Cilauteureun, Sungai Cipasanggrahan, dan Sungai Cimangke. Perairan Pamengpeuk merupakan salah satu perairan yang terkena pengaruh radionuklida, yaitu Radionuklida Cesium-137 $\left({ }^{137} \mathrm{Cs}\right)$ dimana jenis Cesium ini merupakan logam yang sangat reaktif saat bereaksi dengan air (Aziz et al., 2015). Perairan Selat Sunda hingga Selatan Garut merupakan representasi dari Samudera Hindia yang termasuk ke dalam Zona Ekonomi Ekslusif ZEE Indonesia. Arus yang bergerak tersebut sangat dipengaruhi oleh musim (Wahyono, 2013). Penelitian ini dilakukan untuk mengetahui sebaran dan profil kualitas air serta pengaruh sebaran kualitas air terhadap populasi plankton di Selat Sunda hingga Pameungpeuk.

\section{BAHAN DAN METODE}

Penelitian dilakukan dengan mengambil data parameter kualitas air di 4 stasiun berbeda yang dianggap dapat mewakili gambaran perairan dia area tersebut (metode purposive Sampling), 4 stasiun tersebut tersebar dari Selat Sunda hingga Pameungpeuk Garut pada April 2008. Sampling dilakukan dengan mengikuti kapal

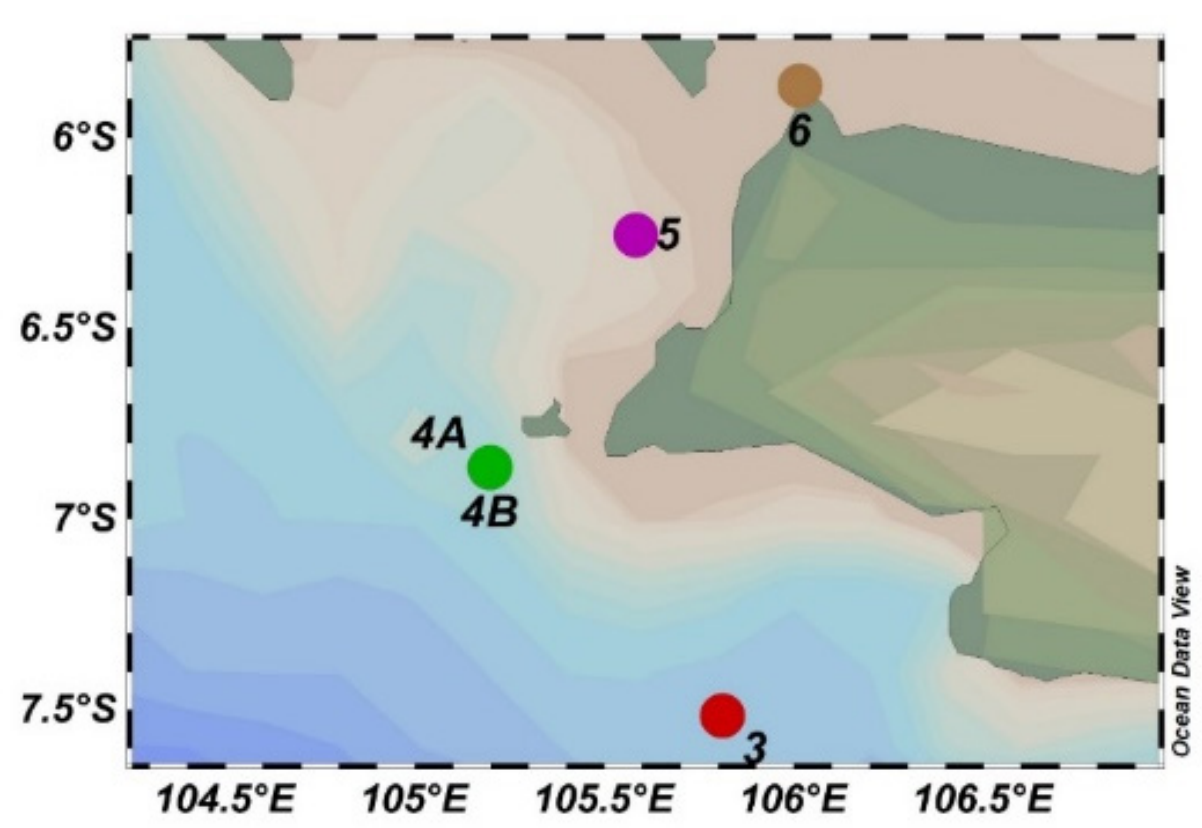

Gambar 1. Lokasi penelitian. Sumber: (Ocean Data View, 2018)

Figure 1. Research location. Source: (Ocean Data View, 2018) 
riset Baruna Jaya. Stasiun 3 diamati pada pukul 11:00 WIB dengan koordinat $7^{\circ} 30.919^{\prime}$ LS $105^{\circ} 48.662$ BT, stasiun 4A diamati pada pukul 18:00 denganf koordinat $6^{\circ} 51.906^{\prime}$ LS $105^{\circ} 11.893^{\prime}$ BT, stasiun 4B diamati pada pukul 07:00 WIB dengan koordinat $6^{\circ} 51.882$ ' LS $105^{\circ} 11.909^{\prime}$, stasiun 5 diamati pada pukul 17:00 dengan koordinat $6^{\circ} 15.351^{\prime}$ LS $105^{\circ} 34.973$ ' BT, dan stasiun 6 diamati pada pukul 21:30 dengan koordinat $5^{\circ} 51.898^{\prime}$ LS $105^{\circ} 1.069^{\prime}$ BT (Gambar 1).

Sampling plankton dilakukan menggunakan Rosette Sampler yang turun perlahan dan akan terbuka pada kedalaman tertentu, yaitu $0 \mathrm{~m}, 25 \mathrm{~m}, 50 \mathrm{~m}, 75 \mathrm{~m}$, dan $100 \mathrm{~m}$. Kemudian, air disaring menggunakan jaring plankton (plankton net) dengan mesh size $20 \mu \mathrm{m}$. Pengawetan plankton dilakukan dengan menggunakan formalin yang sudah disanggah (1 L 37\% formaldehyde $+20 \mathrm{~g}$ sodium borate) sebanyak $40 \mathrm{~mL}$ hingga $1 \mathrm{~L}$ sampel air. Analisis plankton dilakukan terhadap kelimpahan, indeks diversitas, indeks keseragaman, indeks dominansi, dan analisis regresi.

Analisis kelimpahan plankton digunakan untuk mengetahui jenis-jenis fitoplankton dan zooplankton yang ditemukan. Menurut APHA, kelimpahan plankton dilakukan dengan persamaan.

$\mathrm{N}=\frac{n}{p} x \frac{O i}{O p} x \frac{V r}{V o} x \frac{1}{V s}$

dimana,

$\mathrm{N} \quad$ : jumlah individu per liter (ind/L)

$\mathrm{n} \quad$ : adalah jumlah plankton pada seluruh lapang pandang

$\mathrm{p} \quad$ : jumlah lapang pandang yang teramati

Oi : luas Sedgwick Rafter Counting Cell $\left(\mathrm{mm}^{2}\right)$

Op : luas satu lapang pandang $\left(\mathrm{mm}^{2}\right), \mathrm{Vr}$ adalah volume air tersaring $(\mathrm{mL})$,

Vo : volume air yang diamati $(\mathrm{mL})$,

Vs : adalah volume air yang disaring (L).

Analisis indeks diversitas digunakan untuk mengetahui keragaman jenis plankton yang ditemukan. Menurut Parson et al. (1977), indeks diversitas dihitung berdasarkan Shannon-Wiener dengan persamaan.

$$
\mathrm{H}^{\prime}=-\Sigma \frac{n i}{N} \log _{2} \frac{n i}{N}
$$

dimana,

H' : indeks keanekaragaman

ni : adalah jumlah individu jenis ke-i
$\mathrm{N} \quad$ : adalah jumlah total individu.

Analisis indeks keseragaman digunakan untuk mengetahui keseragaman jenis plankton yang ada di setiap stasiun. Menurut Pole (1974) dalam Supono (2009), indeks keseragaman dihitung dengan persamaan

\section{$\mathrm{E}=\frac{H^{\prime}}{\text { Hmaks }}$}

dimana,

E : indeks keseragaman

H' : adalah indeks keanekaragaman

$\mathrm{H}_{\text {maks }} \quad: \log _{2} \mathrm{~S}$

$\mathrm{S}^{\text {maks }} \quad$ jumlah jenis

Analisis indeks dominansi digunakan untuk mengetahui sejauh mana plankton dapat mendominasi kelompok plankton lainnya. Menurut Odum (1996), indeks dominansi dihitung dengan persamaan.

$\mathrm{C}=-\Sigma\left(\frac{n i}{N}\right)^{2}$

dimana,

ni : jumlah individu jenis ke-I dan $\mathrm{N}$ adalah jumlah total individu.

Analisis regresi digunakan untuk mengetahui pengaruh stasiun dan kedalaman terhadap kelimpahan plankton.

\section{HASIL DAN PEMBAHASAN}

Gambar 2 menunjukkan sebaran suhu cenderung sama di setiap kedalaman dan stasiunnya. Semakin mendekati Samudera Hindia, suhu semakin menurun yang ditunjukkan pada stasiun 3. Semakin mendekati Selat Sunda, suhu semakin meningkat yang ditunjukkan pada stasiun 6. Perbedaan suhu tersebut menunjukkan adanya sirkulasi horizontal di lapisan permukaan. Semakin dalam perairan, suhu akan semakin menurun disebabkan karena kurangnya pengaruh cahaya matahari yang dapat menembus pada perairan yang dalam. Menurut Kalangi et al. (2013), faktor yang mempengaruhi persebaran suhu perairan adalah angin, arus pasang surut, dan perbedaan gradien tekanan. Kecepatan angin akan menimbulkan gaya friksi di permukaan laut yang menimbulkan terjadinya pergerakan massa air. Pasang surut mengakibatkan terjadinya pengadukan dasar laut yang umumnya terjadi di daerah pantai sehingga daerah pantai memiliki 

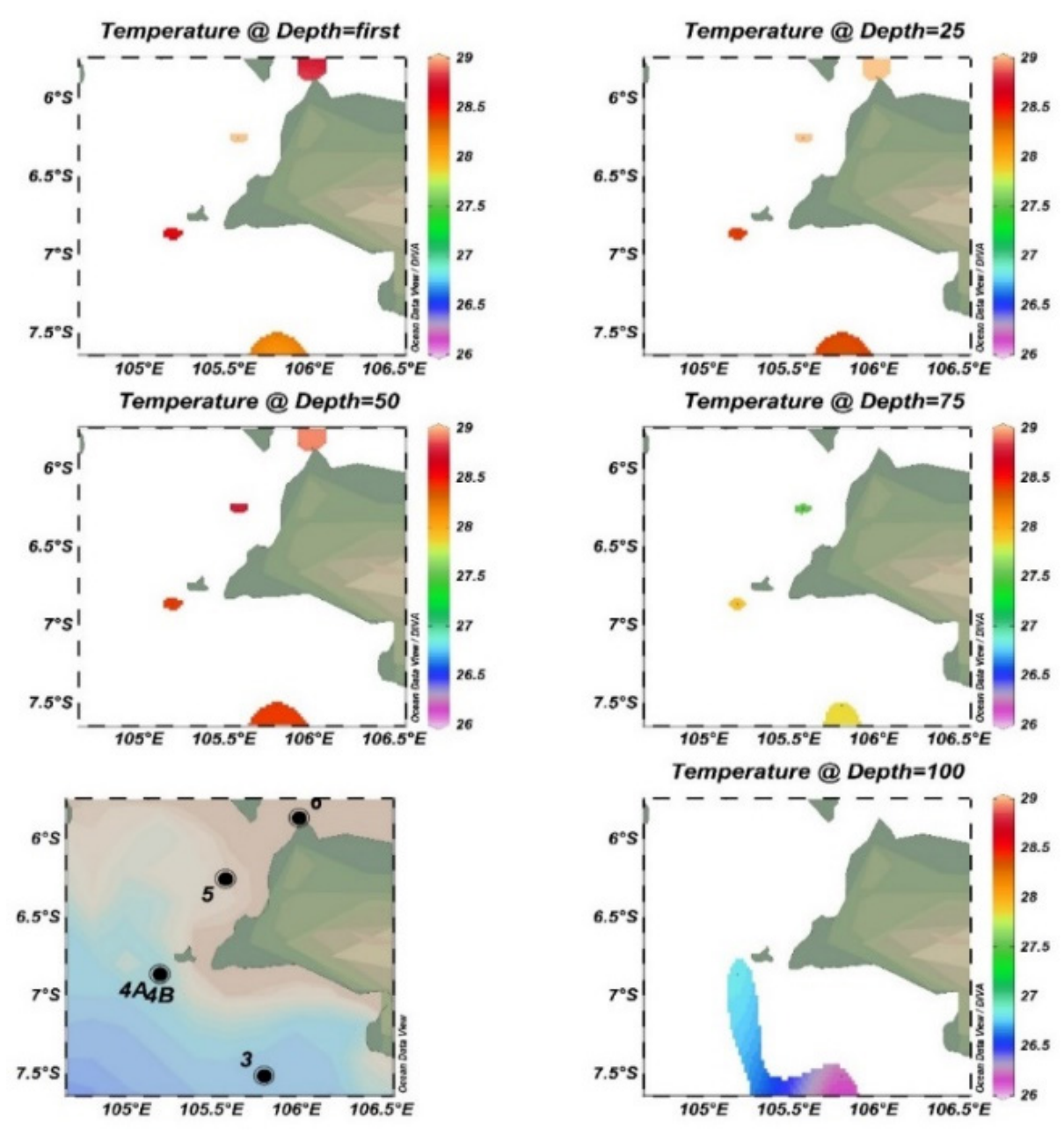

Gambar 2. Sebaran suhu pada seluruh kedalaman.

Sumber: Hasil pengamatan diolah dengan Ocean Data View

Figure 2. Temperature distribution at all depths.

Source: Observation results processed with Ocean Data View

banyak unsur hara dan sedimen yang menyebabkan suhu menjadi lebih tinggi dibandingkan lautan lepas. Perbedaan gradien tekanan disebabkan karena adanya masukan perairan dari sungai ke laut sehingga suhu di daerah pantai akan lebih tinggi. Selain itu, suhu perairan dapat dipengaruhi oleh posisi matahari, letak geografis, musim, kondisi atmosfir, dan batimetri (Kalangi et al, 2013; Kusmanto et al., 2016).

Gambar 3 menunjukkan semakin mendekati Samudera Hindia (stasiun 3), salinitas semakin tinggi dan semakin mendekati Selat Sunda (stasiun 6), salinitas semakin rendah. Semakin bertambah kedalaman, salinitas semakin tinggi, begitu pula sebaliknya. Menurut Kalangi et al. (2013), salinitas dipengaruhi oleh beberapa faktor, yaitu penguapan, curah hujan, dan masukan air sungai. Stasiun 5 dan 6 merupakan daerah Selat Sunda yang sangat dipengaruhi oleh masukan air sungai. Salah satu sungai besar yang bermuara di Selat Sunda adalah kali Grogol. Adanya masukan air sungai menyebabkan terjadinya pola variasi salinitas. Pola variasi salinitas di lautan lepas lebih dipengaruhi oleh penguapan yang menyebabkan rendahnya salinitas. Jumlah salinitas di laut juga akan selalu sama walaupun terjadi penguapan. Tingginya nilai salinitas di stasiun 3 dan 4 atau mendekati Samudera Hindia disebabkan karena tidak adanya pengaruh masukan dari sungai.

Profil suhu di setiap stasiun menunjukkan pola yang sama, yaitu semakin bertambahnya kedalaman, kondisi suhu semakin menurun. Kondisi berbeda untuk stasiun 5 dan 6 dimana suhu cenderung homogen dari permukaan sampai kedalaman 50-75 $\mathrm{m}$, hal ini dapat terjadi akibat pengaruh angin yang masih dominan pada kedalaman tersebut. Profil suhu secara vertikal dibedakan menjadi 3 lapisan, yaitu Mixed layer, thermocline layer, dan deep layer. Mixed layer adalah lapisan paling atas di suatu perairan yang tercampur sempurna dan memiliki suhu yang cenderung hangat karena masih terpengaruh oleh paparan matahari dan 

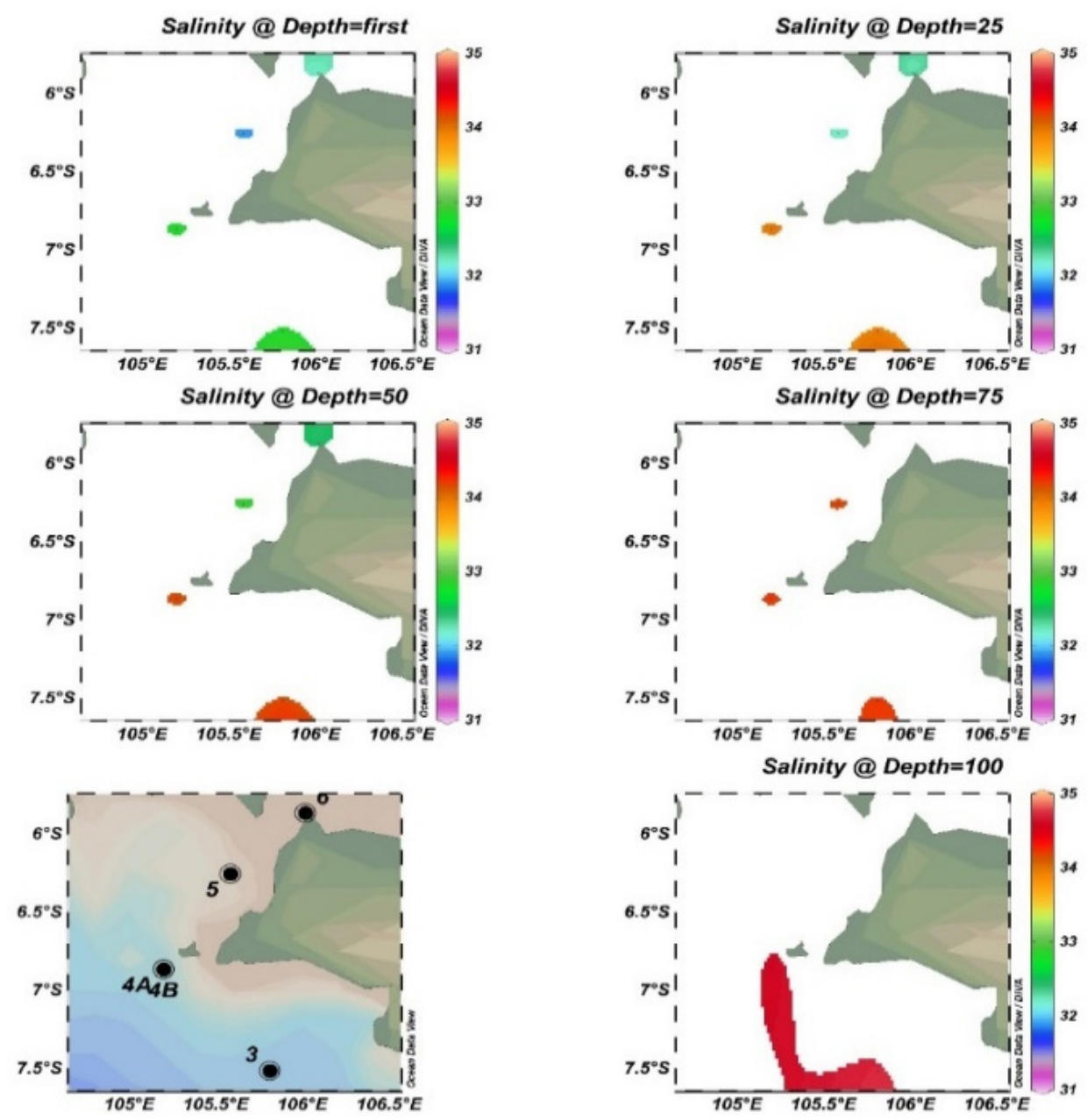

Gambar 3. Sebaran salinitas pada seluruh kedalaman.

Sumber: Hasil pengamatan diolah dengan Ocean Data View

Figure 3. Distribution of salinity at all depths.

Source: Observation results processed with Ocean Data View

memiliki gradien suhu yang tidak besar. Thermocline layer adalah lapisan yang mengalami penurunan suhu secara drastis dan memiliki gradien $0,1^{\circ} \mathrm{C}$ per meter. Deep layer adalah lapisan dalam yang memiliki suhu relatif konstan. (Nontji, 1987), Kalangi et al. (2013)). Profil suhu menunjukkan lapisan termoklin ditemui mulai pada kedalaman sekitar $75 \mathrm{~m}$. Hal ini ditunjukkan dengan adanya perubahan suhu yang sangat drastis dari $25^{\circ} \mathrm{C}-30^{\circ} \mathrm{C}$ menjadi $10^{\circ} \mathrm{C}-15^{\circ} \mathrm{C}$. Gambar 4 juga menunjukkan bahwa setiap stasiun memiliki suhu yang tidak berbeda jauh.

Profil salinitas menunjukkan terjadinya perubahan salinitas pada kedalaman sekitar $75 \mathrm{~m}$. Perubahan tidak terjadi secara drastis karena salinitas laut berkisar antar 25-35 ppt. Berbeda dengan suhu, semakin dalam perairan, salinitas semakin meningkat. Menurut Kalangi et al. (2013), perubahan salinitas tidak terjadi secara linier. Parameter salinitas juga memiliki perbedaan di setiap lapisan. Lapisan paling atas disebut dengan
Mixed layer, yaitu lapisan yang memiliki salinitas tercampur sempurna yang disebabkan karena adanya pengaruh dari air sungai, curah hujan, dan penguapan. Lapisan tengah disebut halocline layer, yaitu suatu lapisan tengah perairan yang dicirikan dengan nilai salinitas yang mengalami perubahan secara drastis dan terjadi di daerah muara atau estuari. Lapisan paling bawah disebut dengan deep layer yang memiliki salinitas stabil (Garrison, 2004 dalam Kalangi et al, 2013).

Fitoplankton yang ditemukan adalah diatom, yaitu sebesar 92\%, sedangkan sisanya adalah dinoflagellata. Hal ini sesuai dengan penelitian Amri et al. (2014), dimana ditemukan diatom sebesar 98,5\% di Selat Sunda. Selain itu, juga sesuai dengan penelitian Khasanah et al. (2013), dimana ditemukan diatom sebesar $95,9 \%$ di Samudera Hindia bagian selatan Pulau Jawa (Gambar 5). 

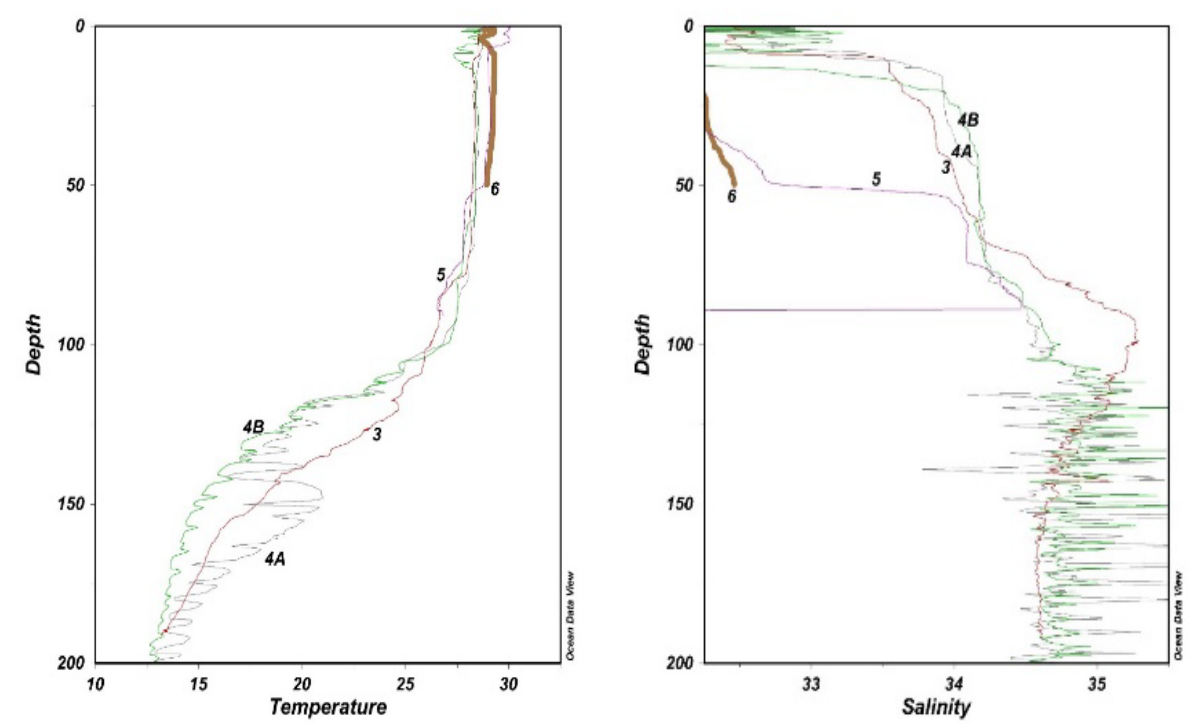

Gambar 4. Profil suhu dan salinitas.Sumber: Hasil pengamatan diolah dengan Ocean Data View

Figure 4. Temperature and salinity profile. Source: Observation results processed with Ocean Data View

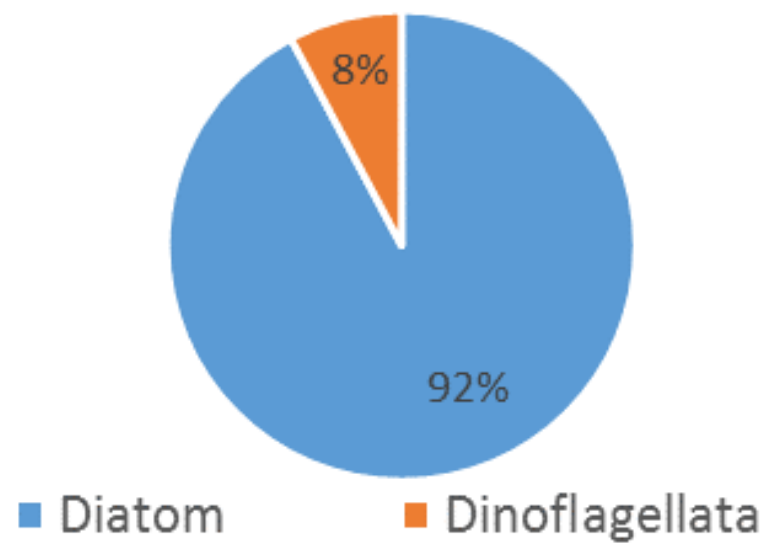

Gambar 5. Komposisi fitoplankton. Sumber: Hasil pengamatan diolah dengan Microsoft Excel

Figure 5. Phytoplankton composition. Source: Observation results processed with Microsoft Excel

Kelimpahan fitoplankton tertinggi terjadi pada stasiun 5 kedalaman $50 \mathrm{~m}$ dengan nilai $6.825 \mathrm{ind} / \mathrm{L}$ yang ditunjukkan pada Gambar 6. Jenis fitoplankton yang banyak ditemui adalah Chaetoceros sebesar 2.450 ind/L. Chaetoceros memiliki rentang hidup dengan suhu $-2-29^{\circ} \mathrm{C}$ dan salinitas 20-36 ppt (Scott, 2015). Stasiun 5 kedalaman $50 \mathrm{~m}$ memiliki suhu $28,7^{\circ} \mathrm{C}$ dan salinitas $32,8 \mathrm{ppt}$, artinya tempat ditemukannya Chaetoceros sesuai dengan suhu dan salinitas hidupnya. Kelimpahan fitoplankton terbanyak ditemukan pada kedalaman $50 \mathrm{~m}$ di stasiun 5 disebabkan karena waktu Sampling dilakukan pada pukul 17:00 dimana matahari sudah mulai terbenam sehingga fitoplankton cenderung mengumpul di bawah permukaan.

Kelimpahan zooplankton tertinggi terdapat pada kedalaman $50 \mathrm{~m}$ di stasiun 3, dimana ditemukan nauplii copepod sebesar 1.708 ind/L yang ditunjukkan pada Gambar 7. Copepod memiliki toleransi terhadap salinitas 28-34 ppt dan suhu $26-30^{\circ} \mathrm{C}$ (Santhanam \& Perumal, 2012). Stasiun 3 kedalaman $50 \mathrm{~m}$ memiliki suhu 34,1 ppt dan suhu $28,4^{\circ} \mathrm{C}$, artinya tempat ditemukannya nauplii copepod sudah sesuai dengan kemampuan hidupnya. Zooplankton memiliki sifat hidup migrasi nokturnal, yaitu organisme yang aktif berpindah dari tempat dalam ke tempat dangkal pada malam hari (Moniharapon et al., 2014). Zooplankton merupakan organisme yang memiliki sifat fototaksis negatif (Zulfiandi et al., 2014). Kelimpahan zooplankton tertinggi ditemukan pada kedalaman 50 $\mathrm{m}$ karena pengamatan stasiun 3 dilakukan pada pukul 11:00 sehingga zooplankton cenderung berada pada di bawah permukaan. 


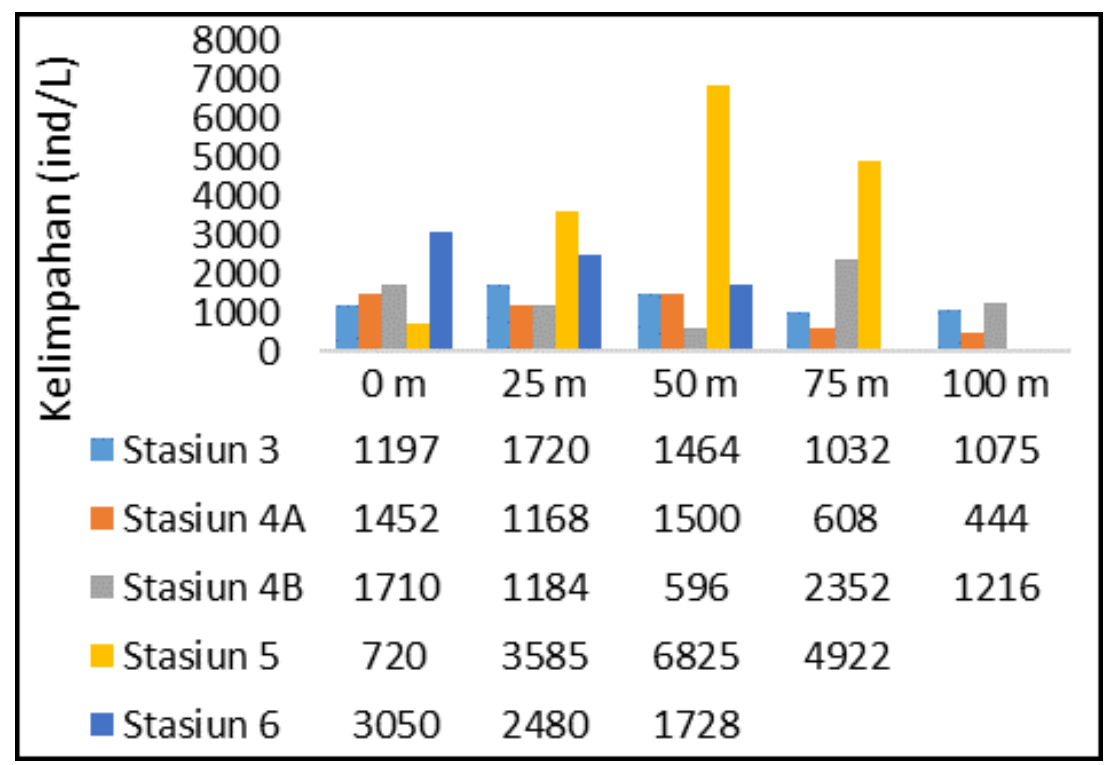

Gambar 6. Kelimpahan fitoplankton. Sumber: Hasil pengamatan diolah dengan Microsoft Excel

Figure 6. Phytoplankton abundance. Source: Observation results processed with Microsoft Excel

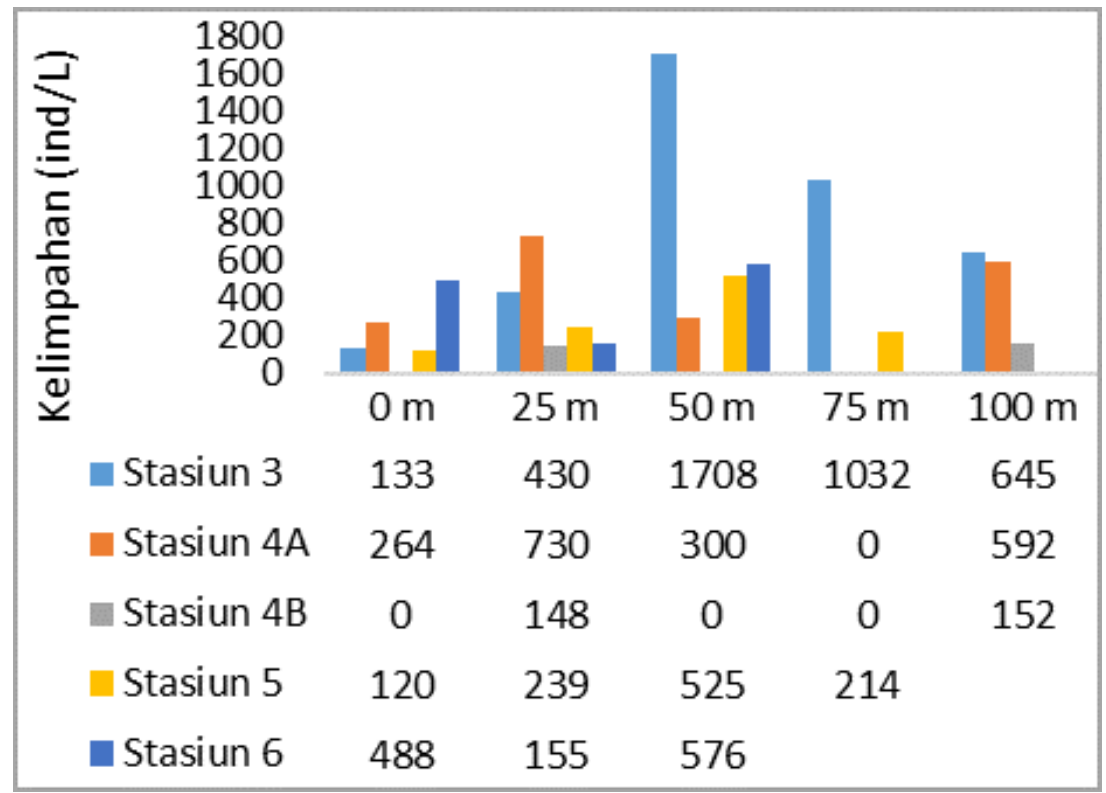

Gambar 7. Kelimpahan zooplankton. Sumber: Hasil pengamatan diolah dengan Microsoft Excel

Figure 7. Abundance of zooplankton. Source: Observation results processed with Microsoft Excel

Diversitas fitoplakton tertinggi adalah 2,61 ditemukan pada kedalaman $25 \mathrm{~m}$ di stasiun 5 dengan rata-rata diversitas seluruhnya adalah 2 yang ditunjukkan pada Gambar 8. Menurut Prawiradilaga et al. (2003), apabila $H^{\prime}$ atau diversitas berkisar antara $1-3$ artinya keanekaragaman sedang, $H^{\prime}$ lebih dari 3 artinya keanekaragaman tinggi, dan H' kurang dari 1 artinya keanekaragaman rendah, artinya keanekaragaman di lokasi pengamatan bersifat sedang. Fitoplankton yang ditemukan pada kedalaman $25 \mathrm{~m}$ di stasiun 5 terdiri dari 7 genus dengan jumlahnya yang melimpah sehingga nilai diversitasnya tinggi. Keanekaragaman yang tinggi tersebut dapat disebabkan karena letak stasiun 5 yang merupakan daerah pertemuan Laut Jawa dan Samudera Hindia sehingga kondisi makanannya terpenuhi dan cahaya matahari dapat menembus hingga kedalaman $25 \mathrm{~m}$. Diversitas zooplankton tidak dapat ditampilkan karena zooplankton yang ditemui hanya terdiri dari 2 jenis, yaitu nauplii copepod dan nauplius.

Keseragaman fitoplankton tertinggi adalah 1 yang terdapat pada kedalaman $0 \mathrm{~m}$ stasiun 5 , kedalaman 50 $\mathrm{m}$ stasiun 4 pagi hari, kedalaman $75 \mathrm{~m}$ stasiun 4 malam hari, dan kedalaman $100 \mathrm{~m}$ stasiun 4 malam hari, serta rata-rata keseragaman fitoplankton yang ditemukan adalah 0,85. Kriteria keseragaman terdiri dari 3, yaitu 


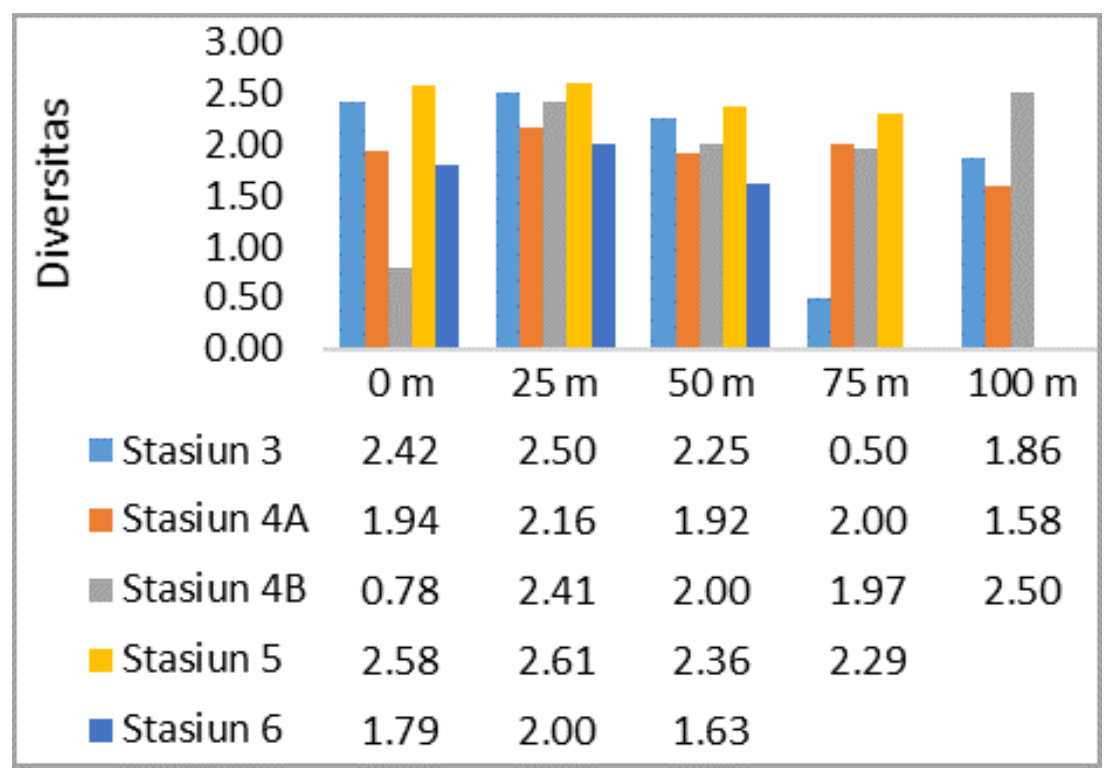

Gambar 8. Diversitas fitoplankton. Sumber: Hasil pengamatan diolah dengan Microsoft Excel Figure 8. Diversity of phytoplankton. Source: Observation results processed with Microsoft Excel

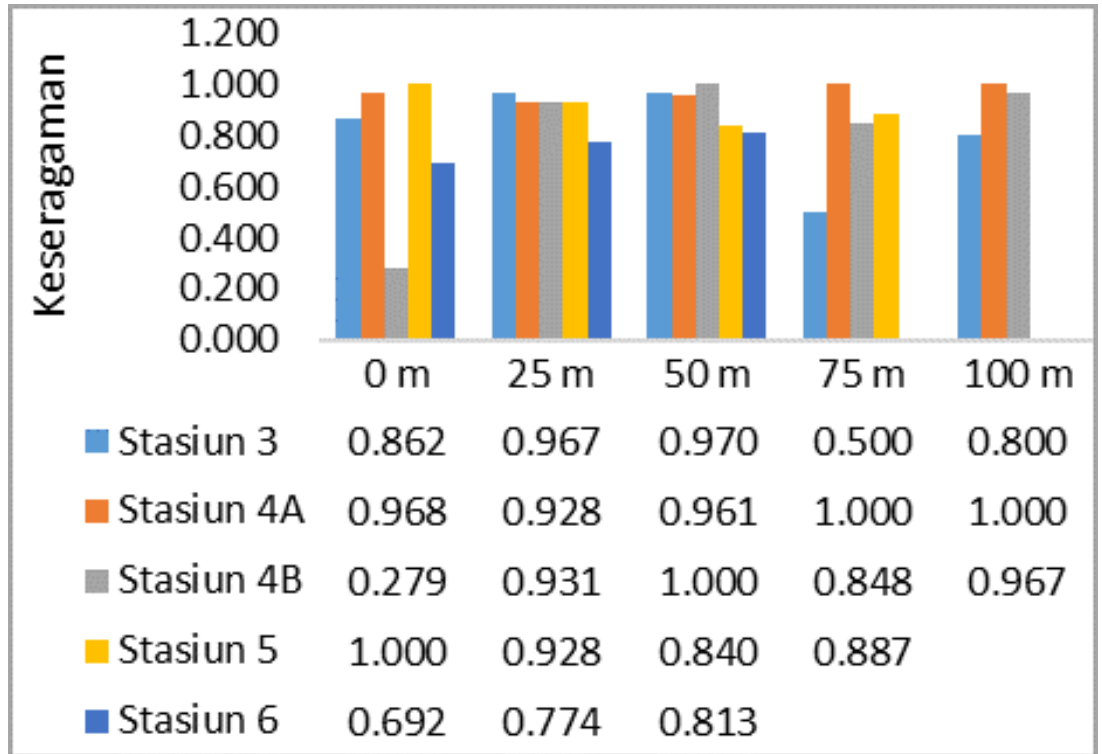

Gambar 9. Phytoplankton uniformity. Source: Observation results processed with Microsoft ExcelFigure

Figure 9. Phytoplankton uniformity. Source: Observation results processed with Microsoft ExcelFigure

apabila e $<0,4$ termasuk kategori rendah, $0,4<\mathrm{e}<$ 0,6 termasuk kategori sedang, dan e $>0,6$ termasuk kategori tinggi (Arinardi et al., 1996). Fitoplankton di lokasi penelitian memiliki keseragaman tinggi, artinya fitoplankton yang ditemui memiliki sifat yang seragam. Menurut Munthe et al. (2012), nilai keseragaman yang semakin mendekati 1 artinya komunitas bersifat stabil dan jumlah individu antarspesies sama. Keseragaman zooplankton bernilai 0 karena hanya ditemukan 1 dari 2 jenis zooplankton di setiap kedalaman dan stasiunnya. Dominansi fitoplankton tertinggi adalah 1,46 pada kedalaman $75 \mathrm{~m}$ di stasiun 4B dan rata-rata dominansi fitoplankton yang ditemukan adalah 0,32. Menurut
Munthe et al. (2012), kriteria indeks dominansi plankton terdiri dari 2 , yaitu $0<\mathrm{C} \leq 0,5$ artinya tidak ada genus yang mendominasi dan $0,5<\mathrm{C}<1$ artinya terdapat genus yang mendominasi, artinya pada stasiun 4B terdapat genus yang sangat mendominasi. Menurut Odum (1993) dalam Afif et al. (2014), nilai dominansi berbanding terbalik dengan nilai keseragaman. Nilai dominansi yang mendekati 0 menunjukkan bahwa komunitas di perairan tersebut stabil dan tidak terdapat tekanan ekologis terhadap biota di perairan tersebut. Genus yang mendominasi pada kedalaman $75 \mathrm{~m}$ di stasiun 4B adalah Skeletonema dengan nilai 1.029 ind/L. 


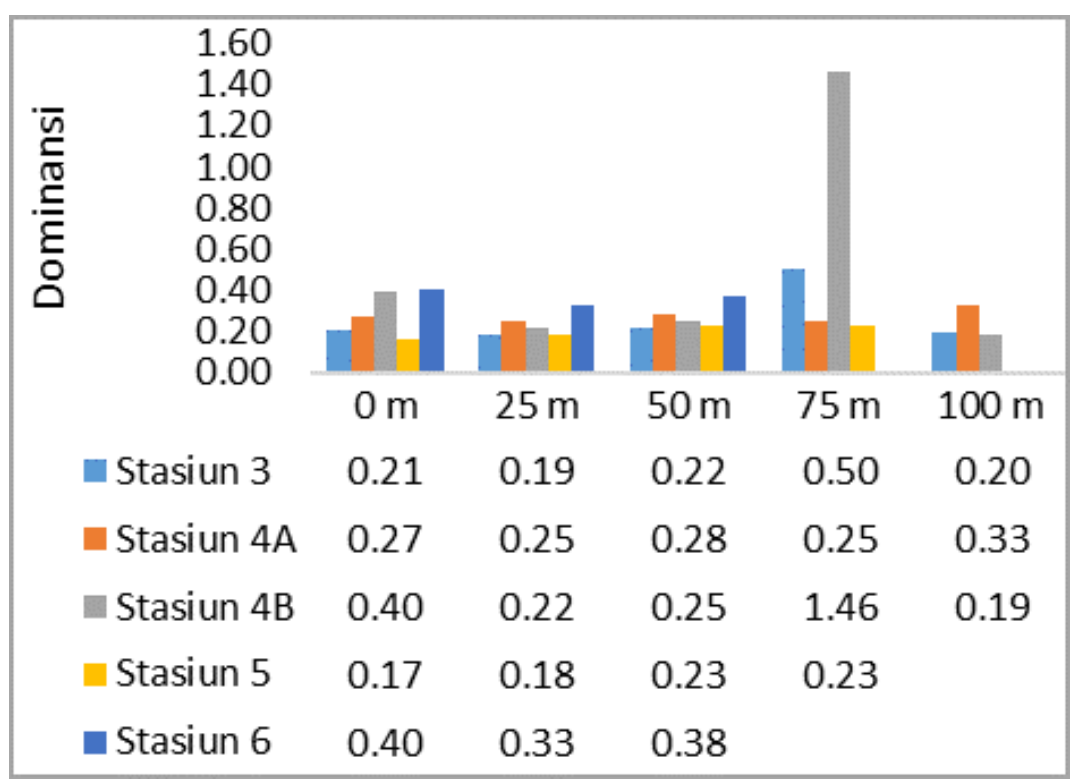

Gambar 10. Dominansi fitoplankton. Sumber: Hasil pengamatan diolah dengan Microsoft Excel Figure 10. Phytoplankton dominance. Source: Observation results processed with Microsoft Excel

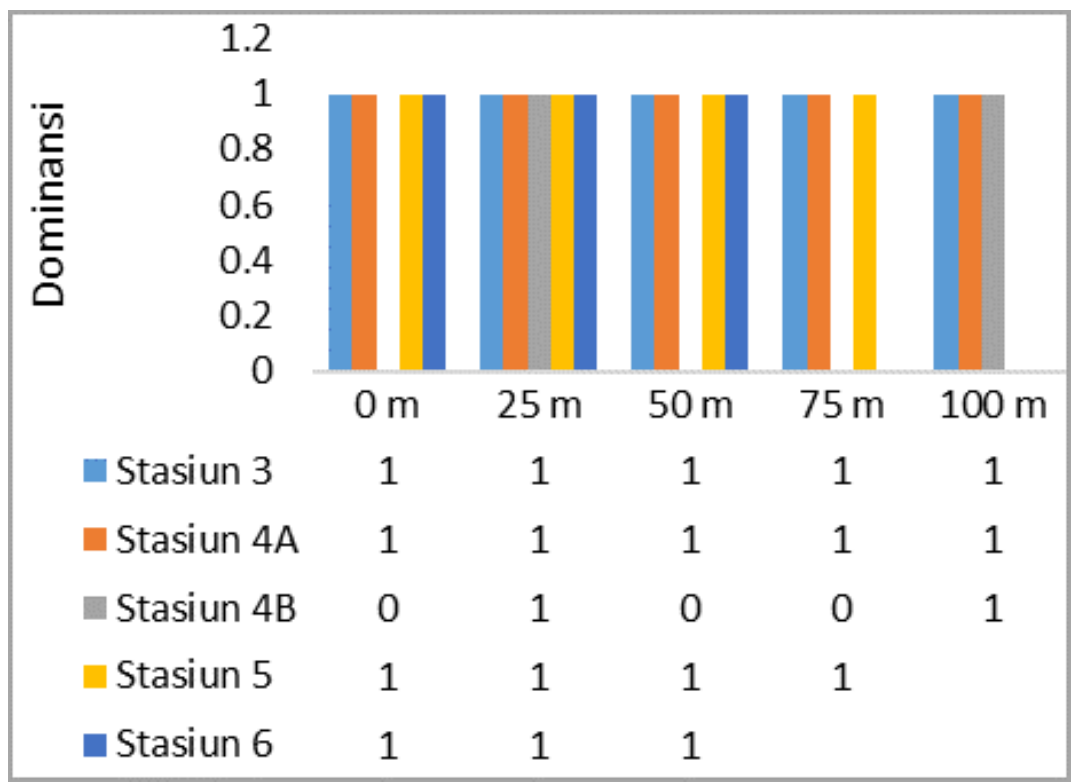

Gambar 11. Dominansi zooplankton. Sumber: Hasil pengamatan diolah dengan Microsoft Excel

Figure 11. Dominance of zooplankton. Source: Observation results processed with Microsoft Excel

Setiap satu kedalaman dalam satu stasiun, hanya ditemui salah satu dari dua jenis zooplankton sehingga dominansi bernilai 1 seperti yang ditunjukan pada Gambar 11., artinya hanya jenis tersebut yang mendominasi di perairan tersebut. Nilai dominansi yang bernilai 0 disebabkan karena tidak ditemuinya satu jenis pun zooplankton di dalam perairan tersebut. Uji regresi fitoplankton dilakukan untuk mengetahui pengaruh stasiun dan kedalaman terhadap kelimpahan fitoplankton. Stasiun memiliki signifikansi sebesar 0,269 terhadap kelimpahan fitoplankton, artinya stasiun tidak memiliki pengaruh yang nyata terhadap kelimpahan fitoplankton. Kedalaman memiliki signifikansi 0,284 terhadap kelimpahan fitoplankton, artinya kedalaman tidak memiliki pengaruh yang nyata terhadap kelimpahan fitoplankton. Tabel 1 menunjukkan bahwa nilai $\mathrm{Y}=1416,3+284,4 \mathrm{X} \neg 1-$ $9,6 \mathrm{X} 2$, artinya setiap terjadi penambahan stasiun sebesar 1, maka kelimpahan fitoplankton akan bertambah sebesar 284,4. Apabila terjadi penambahan kedalaman sebesar 1, maka kelimpahan fitoplankton akan berkurang sebesar 9,6. Hal ini dibuktikan dengan nilai kelimpahan fitoplankton tertinggi terjadi pada kedalaman $50 \mathrm{~m}$ di stasiun 5. Sedangkan, kelimpahan fitoplankton terendah terjadi pada kedalaman $100 \mathrm{~m}$ di stasiun 4 yang diamati pada malam hari. 
Tabel 1. Uji regresi fitoplankton

Table 1. Phytoplankton regression test

\begin{tabular}{|c|c|c|c|c|c|}
\hline \multirow{2}{*}{ Model } & \multicolumn{2}{|c|}{ Unstandardized Coefficient } & \multirow{2}{*}{$\begin{array}{c}\text { Standardized } \\
\text { Coefficients } \\
\text { Beta }\end{array}$} & \multirow{2}{*}{$\mathrm{t}$} & \multirow{2}{*}{ Sig. } \\
\hline & B & Std. Error & & & \\
\hline (Constant) & 1416,36 & 847,95 & & 1,67 & 0,109 \\
\hline Stasiun & 284,4 & 218,94 & 0,229 & 1,13 & 0,269 \\
\hline Kedalaman & $-9,61$ & 8,76 & $-0,222$ & $-1,09$ & 0,284 \\
\hline
\end{tabular}

Tabel 2. Uji regresi zooplankton

Table 2. Zooplankton regression test

\begin{tabular}{|c|c|c|c|c|c|}
\hline \multirow[t]{2}{*}{ Model } & \multicolumn{2}{|c|}{ Unstandardized Coefficient } & \multirow{2}{*}{$\begin{array}{c}\begin{array}{c}\text { Standardized } \\
\text { Coefficients }\end{array} \\
\text { Beta }\end{array}$} & \multirow[t]{2}{*}{$\mathrm{t}$} & \multirow[t]{2}{*}{ Sig. } \\
\hline & $\mathrm{B}$ & Std. Error & & & \\
\hline (Constant) & 700,32 & 203,5 & & 3,44 & 0,002 \\
\hline Stasiun & $-124,92$ & 52,54 & $-0,452$ & $-2,37$ & 0,027 \\
\hline Kedalaman & 0,25 & 2,1 & 0,023 & 0,12 & 0,907 \\
\hline
\end{tabular}

Kelimpahan plankton di suatu perairan dapat dipengaruhi oleh berbagai faktor dan jenis dari fitoplanktonnya itu sendiri, sehingga keberadaannya akan sangat ditentukan lokasi penelitian, waktu pengambilan sampel, keberadaan unsur hara yang menjadi makanannya sehingga kedalaman ditemukannya plankton ini akan berbeda-beda termasuk pula kemampuan planktonnya itu sendiri untuk bertahan hidup. (Siregar et al., 2014) dan (Nurfadillah et al., 2012) Hal ini sejalan dengan penelitian yang dilakukan, dimana fitoplankton yang ditemukan memiliki adaptasi yang tinggi terhadap lingkungan pada kedalaman $50 \mathrm{~m}$ di stasiun 5 yang mana memiliki suhu $28,7^{\circ} \mathrm{C}$ dan salinitas 32,8 ppt.

Kedalaman memiliki nilai signifikansi 0,907 terhadap kelimpahan zooplankton, artinya kedalaman tidak memberikan pengaruh yang nyata terhadap kelimpahan zooplankton. Stasiun memiliki nilai signifikansi sebesar 0,027 yang mana nilainya lebih kecil dari 0,05, artinya stasiun memiliki pengaruh yang nyata terhadap kelimpahan zooplankton. Hal ini diperkuat dengan kelimpahan zooplankton tertinggi terjadi pada stasiun 3 kedalaman $50 \mathrm{~m}$. Tabel 5 menunjukkan bahwa $\mathrm{Y}=700,3-124,9 \mathrm{X} 1+0,250 \mathrm{X} 2$, artinya, semakin bertambah stasiun lokasi pengamatan, kelimpahan zooplankton akan menurun sebesar 124.9. Apabila terjadi penambahan kedalaman, zooplankton akan bertambah sebesar 0,250. Zooplankton memiliki sifat migrasi nokturnal dan fototaksis negatif sehingga banyak zooplankton yang ditemukan pada malam hari di permukaan. Hal ini juga berkaitan dengan larva ikan yang sering muncul pada malam hari untuk memakan zooplankton, sedangkan pada siang hari, jumlahnya melimpah di bawah permukaan.

\section{KESIMPULAN DAN SARAN}

Sebaran horizontal menunjukkan bahwa Selat Sunda memiliki suhu yang lebih tinggi dan salinitas yang lebih rendah dibandingkan stasiun yang semakin mendekati Samudera Hindia. Sebaran vertikal menunjukkan bahwa semakin ke dalam, suhu akan menurun secara drastis pada lapisan termoklin dan salinitas meningkat yang ditemukan pada kedalaman sekitar $75 \mathrm{~m}$. Kelimpahan fitoplankton tertinggi terjadi pada kedalaman $50 \mathrm{~m}$ di stasiun 5 dan zooplankton pada kedalaman $50 \mathrm{~m}$ di stasiun 3 . Fitoplankton yang paling banyak ditemukan adalah Chaetoceros. Zooplankton yang banyak ditemukan adalah nauplii copepod. Indeks diversitas fitoplankton tertinggi adalah 2.61. Indeks keseragaman fitoplankton tertinggi adalah 1. Indeks dominansi fitoplankton adalah 1.46, sedangkan zooplankton adalah 1 .

\section{UCAPAN TERIMA KASIH}

Penulis mengucapkan terimakasih kepada Pusat Riset Kelautan, BRSDMKP, KKP dengan memberi kesempatan penulis untuk Praktek Kerja Lapang. Tulisan ini menggunakan sebagian data dari kegiatan "Analisa regional perairan laut dalam kaitannya dengan 
dinamika sumberdaya kelautan \& perikanan perairan Selat Karimata dan Samudera Hindia" dilaksanakan oleh Pusat Riset Wilayah Laut dan Sumberdaya Nonhayati, Badan Riset Kelautan dan Perikanan, Departemen Kelautan dan Perikanan. Semua penulis memiliki kontribusi yang sama dalam penulisan artikel ini.

\section{DAFTAR PUSTAKA}

Amri, K., Priatna, A., \& Suprapto. (2014). Karakteristik oseanografi dan kelimpahan plankton di Perairan Selat Sunda pada musim timur. BAWAL Widya Riset Perikanan Tangkap, 6(1), 11 - 20.

Arinardi, O. H., Trimaningsih, S. H., \& Asnaryanti, E. (1996). Kisaran kelimpahan dan komposisi plankton predominan di Perairan Kawasan Tengah Indonesia. Pusat Penelitian dan Pengembangan Oseanologi-LIPI, Jakarta.

Aziz, M., Hidayanto, E., \& Lestari, D. D. (2015). Penentuan Aktivitas 60Co dan 137Cs pada Sampel Unknown dengan Menggunakan Detektor HPGe. Youngster Physic Journal, 4(1): 189-196.

Afif, A., Widianingsih, \& Hartati, R. (2014). Komposisi dan kelimpahan plankton di Perairan Pulau Gusung Kepulauan Selayar Sulawesi Selatan. Journal of Marine Research, 3(3), 324 - 331.

Kalangi, P. N. I., Madangi, A., Masengi, K. W. A., Luasunaung, A., Pangalila, F. P. T., \& Iwaka, M. (2013). Sebaran suhu dan salinitas di Teluk Manado. Jurnal Perikanan dan Kelautan Tropis, 9(2), 71-75.

Khasanah, R. I., Sartimbul, A., \& Herawati, E. Y. (2013). Kelimpahan dan keanekaragaman plankton di Selat Bali. Jurnal Ilmu Kelautan, 18(4), 193-202.

Kusmanto, E., Hasanudin, M., \& Setyawan, W. B. (2016). Amplifikasi Pasang Surut dan Dampaknya terhadap Perairan Pesisir Probolinggo. Jurnal Oseanologi dan Limnologi di Indonesia, 1(3), 69-80.

Moniharapon, D., Jaya, I., Manik, H., Pujiyati, S., Hestirianoto, T., \& Syahailatua, A. (2014). Migrasi vertikal zooplankton di Laut Banda. Jurnal Kelautan Nasional, 9(3), 143 - 151.
Munthe, Y. V., Aryawati, R., \& Isnaini. (2012). Struktur komunitas dan sebaran fitoplankton di Perairan Sungsang Sumatera Selatan. Maspari Journal. 4(1), 122-130.

Nontji, A. (1987). Laut Nusantara. Djambatan, Jakarta.

Novia, R., Adnan., \& Ritonga, I. R. (2016). Hubungan parameter fisika-kimia perairan dengan kelimpahan plankton di Samudra Hindia bagian barat daya. Jurnal Depik, 5(2), 67 - 76.

Nurfadillah, Damar, A., \& Adiwilaga, E. M. (2012). Komunitas fitoplankton di perairan Danau Laut Tawar Kabupaten Aceh Tengah, Provinsi Aceh. Depik, 1(2), 93-98.

Odum. (1996). Dasar-dasar Ekologi. Gadjah Mada University Press, Yogyakarta.

Parson, T. R., Takashi, M., \& Hargrave, B. (1977). Biological Oceanography Process. Second Edition. Pergamon Press, New York.

Prawiradilaga, D. M., Suyanto, A., Noerdjito, W. A., Salim, A., Purwaningsih, S., Rachmatika., Susiarti, I. \& Shidiq, A. M. (2003). Final Report on Biodiversity of Tesso Nilo. Research Center for Biologi - LIPI and WWF Indonesia, Jakarta.

Santhanam, P., \& Perumal, P. (2012). Effect of temperature, salinity, and algal food concentration on production density, growth, and survival of marine Copepod Oithona rigida. Indian Journal of Marine Geo-Sciences, 41(4), 369-376.

Scott, S. (2015). Chaetoceros. Diakses pada 16 Januari 2-19. https://sites.evergreen.edu/vms/speciesname-and-genus-sas/

Siregar, L. L., Hutabarat, S., \& Muskananfola, M. R. (2014). Distribusi fitoplankton berdasarkan waktu dan kedalaman yang berbeda di Perairan Pulau Menjangan Kecil Karimunjawa. Diponegoro Journal of Maquares, 3(4), 9-14.

Supono. (2009). Analisis Diatom Epipelic Sebagai Indikator Kualitas Lingkungan Tambak Untuk Budidaya Udang. Master Thesis. Program Studi Magister Manajemen Sumberdaya Pantai, Program Pascasarjana Universitas Diponegoro. Semarang. 
Wahyono, I. B. (2013). Survei kelautan di perairan Samudra Hindia Selatan Jawa Barat. Jurnal Teknologi Pengolahan Limbah, 18(2), 25-30.

Wang, Y., Jiang, H., Jin, J., Zhang, X., Lu, X., \& Wang, Y. (2015). Spatial-temporal variations of chlorophyll-a in the adjacent sea area of the Yangtze River Estuary influenced by Yangtze River. International Journal of Environmental Research and Public Health, 12(5), 5420-5438.

Zulfiandi, Zainuri, M., \& Widowati, I. (2014). Kajian distribusi sebaran fitoplankton dan zooplankton di perairan dan estuaria banjir kanal barat Kota Semarang Jawa Tengah. Seminar Nasional Kelautan: "Kemandirian dalam Rekayasa Teknologi Kelautan dan Pengelolaan Sumberdaya Laut”. 